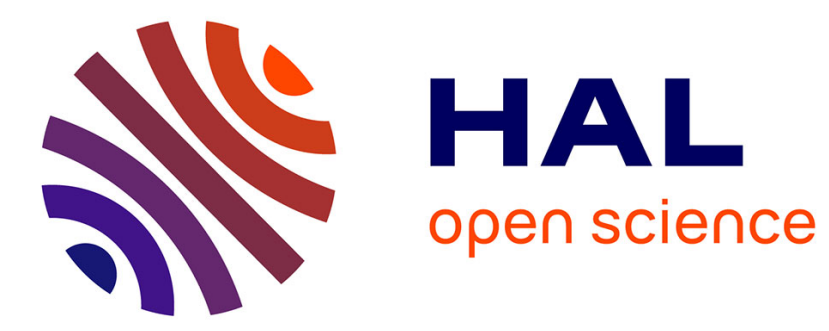

\title{
Mixed-effects modeling for concentration effect profiling in cardiomyocyte contractility assays
}

Levy Batista, Leo Doerr, Krisztina Juhasz, Sonja Stoelzle-Feix, Matthias

Beckler, Thierry Bastogne

\section{- To cite this version:}

Levy Batista, Leo Doerr, Krisztina Juhasz, Sonja Stoelzle-Feix, Matthias Beckler, et al.. Mixed-effects modeling for concentration effect profiling in cardiomyocyte contractility assays. Annual Meeting of Safety Pharmacology Society, SPS 2018, Sep 2018, Washington DC, United States. hal-01925651

\section{HAL Id: hal-01925651 \\ https://hal.science/hal-01925651}

Submitted on 16 Nov 2018

HAL is a multi-disciplinary open access archive for the deposit and dissemination of scientific research documents, whether they are published or not. The documents may come from teaching and research institutions in France or abroad, or from public or private research centers.
L'archive ouverte pluridisciplinaire HAL, est destinée au dépôt et à la diffusion de documents scientifiques de niveau recherche, publiés ou non, émanant des établissements d'enseignement et de recherche français ou étrangers, des laboratoires publics ou privés. 


\section{MIXED-EFFECTS MODELING FOR CONCENTRATION EFFECT PROFILING IN CARDIOMYOCYTE CONTRACTILITY ASSAYS \\ L. BATISTA', L. DOERR², K. JUHASZ2², S. STOELZLE-FEIX², M. BECKLER², T. BASTOGNE1,3,4 \\ 'CYBERnano, ${ }^{2}$ NANION, ${ }^{3}$ CRAN UL-CNRS 7039, 4 INRIA BIGS}

Background. With the advent of new realtime technologies such as impedance assays, extracellular field potential measurement and optical sensing for in vitro cardiac safety screening studies, researchers have now to frequently deal with analyzing voluminous amounts of complex time responses. In this context, main issues are to speed up the data analysis process and to extract accurate information for cardiotoxicity profiling.

\section{Objectives}

A first objective is the development of an innovative computational method able to globally process a large set of in vitro cardiac signals (provided by 96, 384 and 1536-well microplates) instead of analyzing them once at a time. Such a statistical population approach has the advantage the account for the common characteristics between the individual responses. A second objective is to handle qualitative factors (type of cardiomyocytes, compounds and media, etc.) in the computational process.

\section{Methods}

The proposed estimation method relies on the combination of a dynamic system identification method and a mixed-effect modeling technique. An output-error polynomial model structure is used for the system identification step and a stochastic approximation expectation maximization is implemented for the estimation of the hyperparameters. Input signals to be analyzed are the contractility amplitudes of cardiomyocytes submitted to compounds to be tested. Impedance signals and contractility amplitude were provided by a CardioExcyte96 system (Nanion Technologies). human iPSC-derived cardiomyocytes were provided by Cellartis Takara with 30,000 cells per well.

\section{Results}

Our data-driven profiling method extracted four parameters that completely fit the contractility time variations and fully characterize the effect of compound concentration on the contractility amplitude. The proposed method not only estimates the values of the model parameters but also their uncertainty distribution. The latter allows to compute p-values associated with each effect.

\section{Conclusion}

We show that the population-based estimation method developed in this study is suited to the fully characterize dynamic effects in cardiomyocyte contractility assays. Each parameter becomes a profiling characteristics of the concentration effect. It can be applied to estimate concentration and compounds effects with an optimal accuracy and could be extended directly to multielectrode array and optical sensing responses
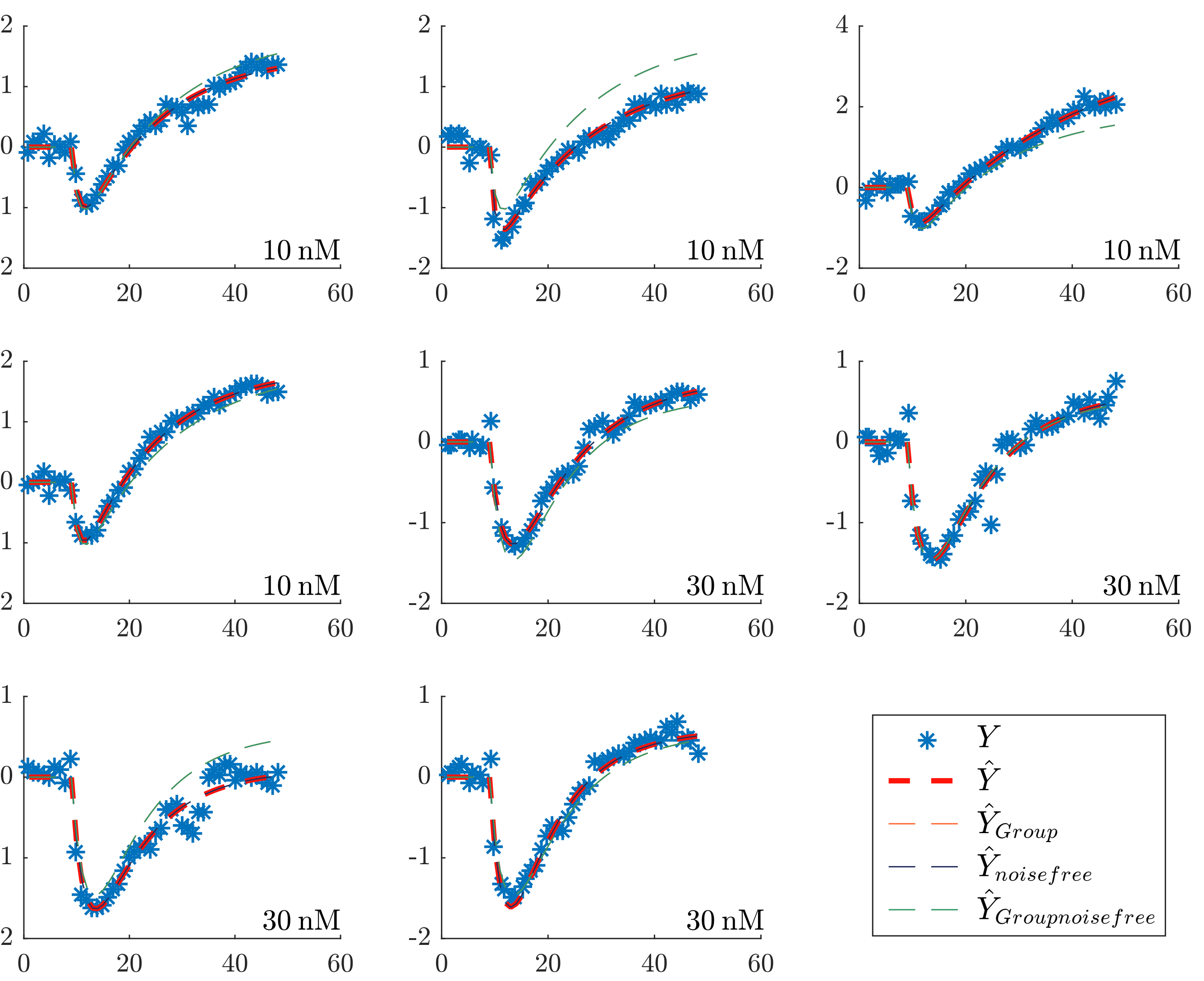

Fig. I Individual time responses (blue stars) of the beating amplitudes for two concentration levels (10nM \& 30nM). Average model responses are presented in red dotted plots.

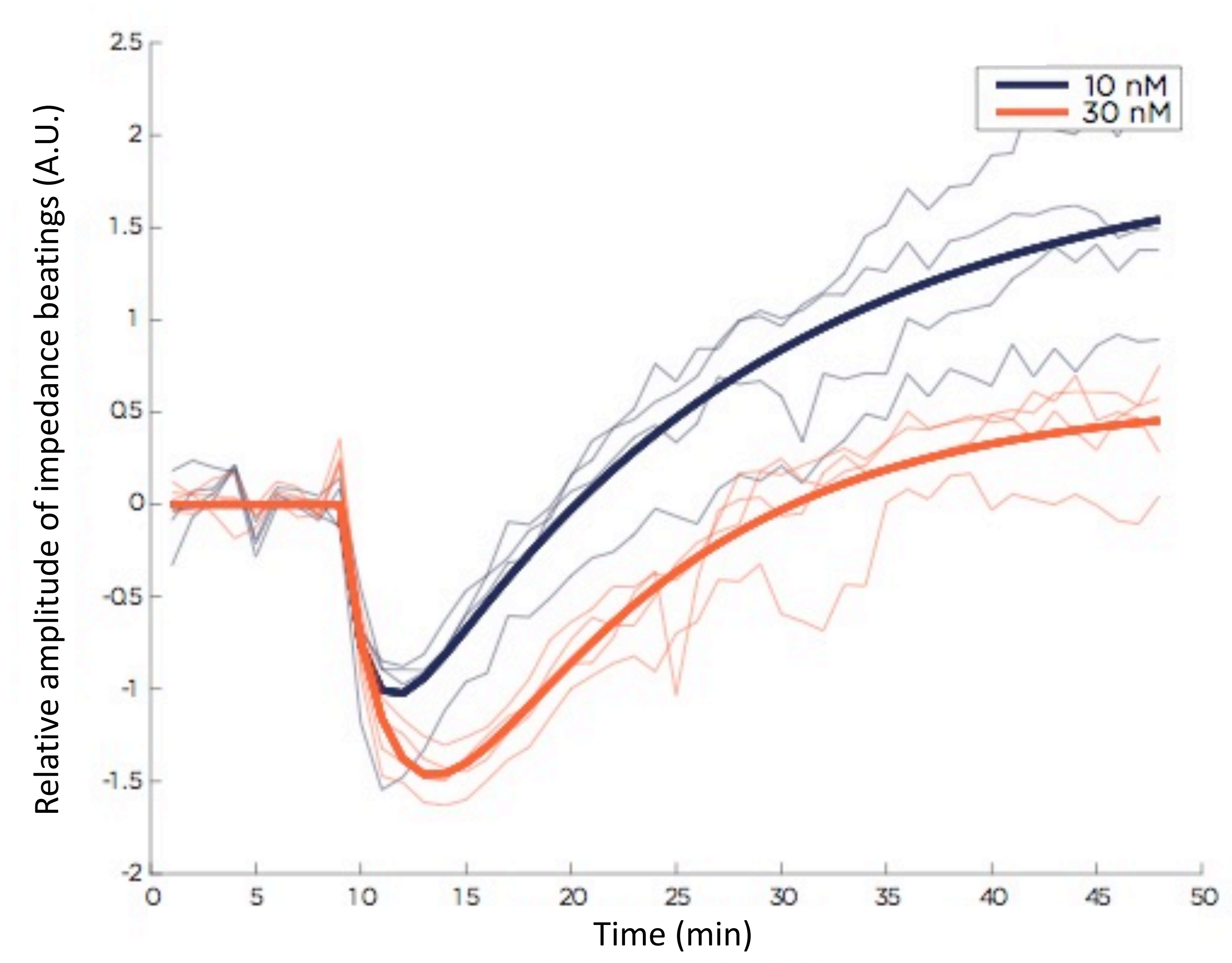

Fig. 2 In bold lines: average responses of the analysis model for the two tested concentrations. We clearly observe a dynamic effect of the compound concentration on the contractility amplitude.

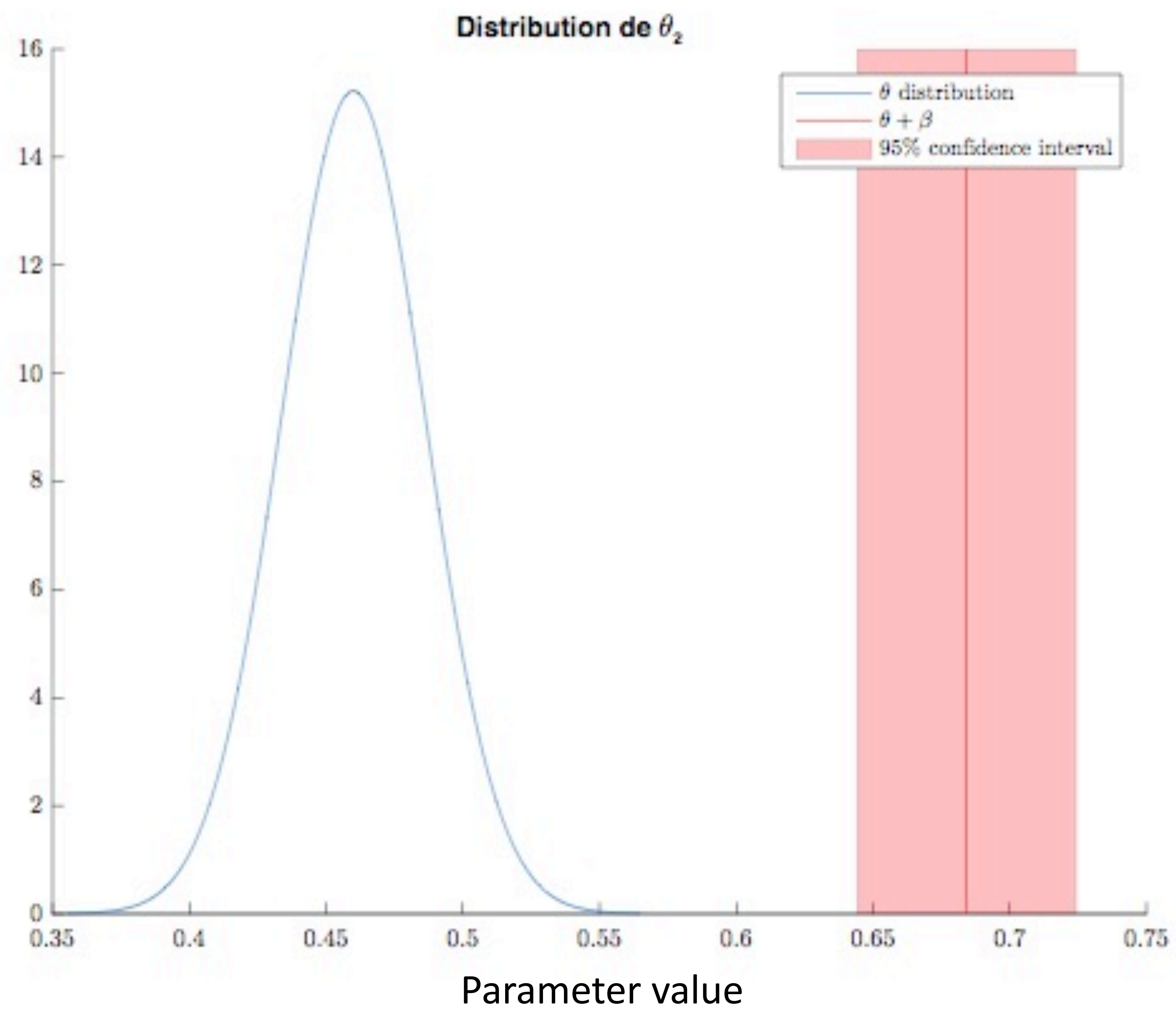

Fig. $3 \theta_{2}$ is a parameter of the mathematical model characterizing the dynamic response of the beating amplitude. Blve: distribution of $\theta_{2}$ for the control group (10nM). Red: mean value of estimation and 95\%-confidence interval for the 30nM group. The gap between the two distributions confirms the relevance of the compound concentration effect and allows to estimate its impact. 